\title{
Effect of Postharvest Treatments and Storage Conditions on Quality Parameters of Carrots
}

\author{
Zoran S. Ilić ${ }^{1}$, Ljubomir Šunić ${ }^{1}$, Saša Barać ${ }^{1}$, Ljiljana Stanojević ${ }^{2}$, Dragan Cvetković ${ }^{2} \&$ Dušan Marinković ${ }^{3}$ \\ ${ }^{1}$ Faculty of Agriculture Priština-Lešak, Lešak 38219, Serbia \\ ${ }^{2}$ Faculty of Technology, University of Niš-Leskovac, Serbia \\ ${ }^{3}$ Faculty of Agriculture, University of Novi Sad, Novi Sad 21000, Serbia \\ Correspondence: Zoran S. Ilić, Faculty of Agriculture Priština-Lešak, Lešak 38219, Serbia. Tel: \\ 381-638-014-966. E-mail: zoran.ilic63@gmail.com
}

Received: February 1, 2013 Accepted: March 3, 2013 Online Published: April 15, 2013

doi:10.5539/jas.v5n5p100 URL: http://dx.doi.org/10.5539/jas.v5n5p100

\begin{abstract}
The purpose of this study was to examine differences between postharvest treatments, either washed (hot water, $\mathrm{H}_{2} \mathrm{O}_{2}$ and $\mathrm{Na}_{2} \mathrm{OCl}$ ) or non-washed (control) carrot roots and the effect of different storage conditions, $\mathrm{S}_{1}\left(0^{\circ} \mathrm{C}\right.$ and $>95 \% \mathrm{RH})$ or $\mathrm{S}_{2}\left(0-2^{\circ} \mathrm{C}\right.$ and $\left.<90 \% \mathrm{RH}\right)$ on the compositional changes. Losses of mass, $\beta$-carotene and vitamin $\mathrm{C}$ in carrot taproot (Daucus carota $\mathrm{L}$. cv.'Maestro $\mathrm{F}_{1}$ ') were monitored during 160 days of cold storage (in both cold room) plus 20 days at $20^{\circ} \mathrm{C}$ (market simulation). At the end of 180 days of storage the percentage mass loss ranged from 3.1 to $33.2 \%$ depending on the storage condition and disinfection treatment. Loss of $\beta$-carotene during storage was higher in the $S_{2}(28.2-46.9 \%)$ than in the $S_{1}$ cold storage $(7.8-20.7 \%)$. The vitamin $C$ loss in carrot root inside the $\mathrm{S}_{1}$ cold room ranged from $2.0 \%$ to $18.2 \%$, while the vitamin $\mathrm{C}$ loss was significantly higher (20.7\%-52.3\%) under simple refrigerated cold storage $\left(\mathrm{S}_{2}\right)$. Our experimental results indicate that prestorage root washing $\left(\mathrm{Na}_{2} \mathrm{OCl}\right)$ significantly reduced weight loss, while hot water treatment maintaining a quality ( $\beta$-carotene and vitamin $\mathrm{C})$. Storage at cold room $\left(\mathrm{S}_{1}\right)$ after these treatments, is a practical strategy for reducing weight loss, $\beta$-carotene and vitamin $\mathrm{C}$ contents in the carrot during prolonged storage.
\end{abstract}

Keywords: Daucus carota, cold room, mass loss, $\beta$-carotene, vitamin C

\section{Introduction}

Carrots (Daucus carota L.) are, in general, one of the best sources of $\beta$-carotene in our diet, and they provide $17 \%$ of the total $\beta$-carotene intake in human nutrition (Alasalvar et al., 2001). $\beta$-carotene is the principal precursor of vitamin A, which is involved in vision, cell differentiation, synthesis of glycoproteins, mucus secretion from the epithelial cells, and overall growth and development of bones. The harvested carrot root is an underground organ that has been dug out of the soil while it was in full metabolic activity. The carrot has low metabolic activity at low temperatures, as shown by the low respiration rate (Stoll \& Weichmann, 1987) and can be stored for 6-8 months without loss of quality under optimal storage conditions (Ilić et al., 2009).

The two basic conditions, as recommended by previous researchers are a temperature of $0^{\circ} \mathrm{C}$ and a relative humidity of 98\% (Afek et al., 1999; Eshel et al., 2009). The most significant changes in postharvest quality are weight loss, bitterness, bacterial deterioration, rooting and sprouting. All of these changes can be prevented by different methods including cold storage, postharvest treatment and chemical applications. Chlorination of process water is one of the primary elements of a proper postharvest sanitation program. Washing carrots with cold chlorinated water $\left(4^{\circ} \mathrm{C}\right)$ and warm tap water $\left(50^{\circ} \mathrm{C}\right)$, respectively, provided good microbiological safety paired with improved sensorial properties (Klaiber et al., 2005). In the last few years, carrot growers in Israel usually applied combined application with stabilized hydrogen peroxide (Tsunami ${ }^{\circledR} 100$ ) or a yeast commercial product (Shemer ${ }^{\mathrm{TM}}$ ) and have begun to brush carrots before storage to remove the outer peel of the root (Eshel et al., 2009). Since carrots are important source of vitamin $\mathrm{C}$ and carotenoids in the human diet, it is appropriate to determine to what extent these compounds are lost during storage. Loss of $\beta$-carotene during carrot storage was observed to be higher in the cellar than in the cold storage (Fikselova et al., 2010). Singh et al. (2001) have reported vitamin C and $\beta$-carotene losses after storage, with higher losses for vitamin C. A thirty-day carrot storage resulted in a significant reduction in vitamin $\mathrm{C}$ content (47\%) and $\beta$-carotene content of 11\% (Matejkova \& Petrikova, 2010). The aim of 
this study was to determine the effectiveness of prestorage treatment in maintaining the quality of carrot during prolonged cold storage.

\section{Material and Methods}

\subsection{Plant Material}

The carrot (Daucus carota L.) cv. 'Maestro $\mathrm{F}_{1}$ ' is a commercial hybrid for open field production during fall, autumn and winter. Uniformly sized taproots at their full maturity stage, about $150 \mathrm{~g}$, were picked directly from a field in the south part of Banat (village Debeljača). The soil conditions were well drained and sandy, and drip irrigation was used. Cultural practices, such as land preparation, planting and plant protection of the crop, were as is the standard in this area. Mature carrots were harvested in the fall and sent into storage immediately after harvest. Taproots without defects or diseases, of same size, shape and injury free were selected for the experiment. The carrots went into storage on November 10, 2011 and the study was terminated on April 20, 2012.

\subsection{Postharvest Treatment}

The following postharvest washing treatments have been conducted: 1-hot water washing and brushing $\left(50^{\circ} \mathrm{C}\right.$ for 1 minute); $2-1 \% \mathrm{H}_{2} \mathrm{O}_{2}$ (tap water for 1 minute); 3-175 ppm $\mathrm{Na}_{2} \mathrm{OCl}$ (tap water for 1 minute); and 4-control, non-washed roots (with soil).

\subsection{Storage Condition}

Following treatment, the taproots were stored for 160 days at different storage conditions. The taproots were stored at $0^{\circ} \mathrm{C}$, in a cold room $\left(\mathrm{S}_{1}\right)$ with high relative humidity (RH 95-98\%) in the dark, or $\left(\mathrm{S}_{2}\right)$ in a cooling room with a temperature of $0-2^{\circ} \mathrm{C}$ and uncontrolled conditions of relative humidity (RH 79-94\%). For each postharvest treatment and storage regimen, 25 roots per replicate were sampled for analysis, with 4 replicates analysed in total. After 160 days storage at either temperature, the taproots were transferred to $20^{\circ} \mathrm{C}$ during 20 days (simulates marketing practices). The analysis of $\beta$-carotene and vitamin $C$ has been carried out after 90,160 and 180 days of storage.

\subsection{Samples and Analysis}

Ten grams of scraped carrot were extracted with $100 \mathrm{ml}$ of $95 \%$ hot ethanol in $400 \mathrm{ml}$ erlenmeyer flask, for 30 minutes. The obtained yellow extract was diluted with water to $85 \%$ of ethanol and cooled down to room temperature. This solution was then transferred to a separatory funnel and mixed well with $50 \mathrm{ml}$ of petroleum ether. The lower, alcoholic phase, was washed with petroleum ether in portions of $2 \mathrm{ml}$, until the upper layer became colorless, which indicates that all carotenes are extracted. Petroleum ether layers have been collected and washed with $85 \%$ ethanol to remove possibly present xanthophylls. The collected petroleum ether layers were concentrated under vacuum at temperature below $40^{\circ} \mathrm{C}$. The remaning oil residue was kept in dark at $4{ }^{\circ} \mathrm{C}$.

HPLC analysis of extracts was carried out with the Agilent 1100 Series system, Waldborn, Germany (pump, detector, software). The LC column Zorbax-Eclipse XDBC18; $4.6 \mathrm{~mm} \times 250 \mathrm{~mm}, 5 \mu \mathrm{m}$ was used. Mobile phase was a mixture of acetonitrile : methanol : ethyl acetate, $6: 2: 2 \mathrm{v} / \mathrm{v}$, flow rate $1 \mathrm{~cm}^{3} / \mathrm{min}$. The injection volume was $20 \mu \mathrm{l}$ using DAD Agilent 1200 Series detector, monitored wavelength was $474 \mathrm{~nm}$ (Cvetkovic and Markovic, 2008).

\subsubsection{Preparation of Extracts for Analysis}

The extracts $\left(8 \mathrm{~cm}^{3}\right)$ of different concentrations were evaporated to dryness with rotary vacuum evaporators at room temperature, and the residues were dissolved in $n$-hexane $\left(2 \mathrm{~cm}^{3}\right)$. Extracts were filtered through a $0.45 \mu \mathrm{m}$ Millipore filter immediately before HPLC analysis. Chromatogram of $\beta$-carotene standard in concentration of $0,00625 \mathrm{mg} / \mathrm{cm}^{3}$ is shown on (Figure 1). 


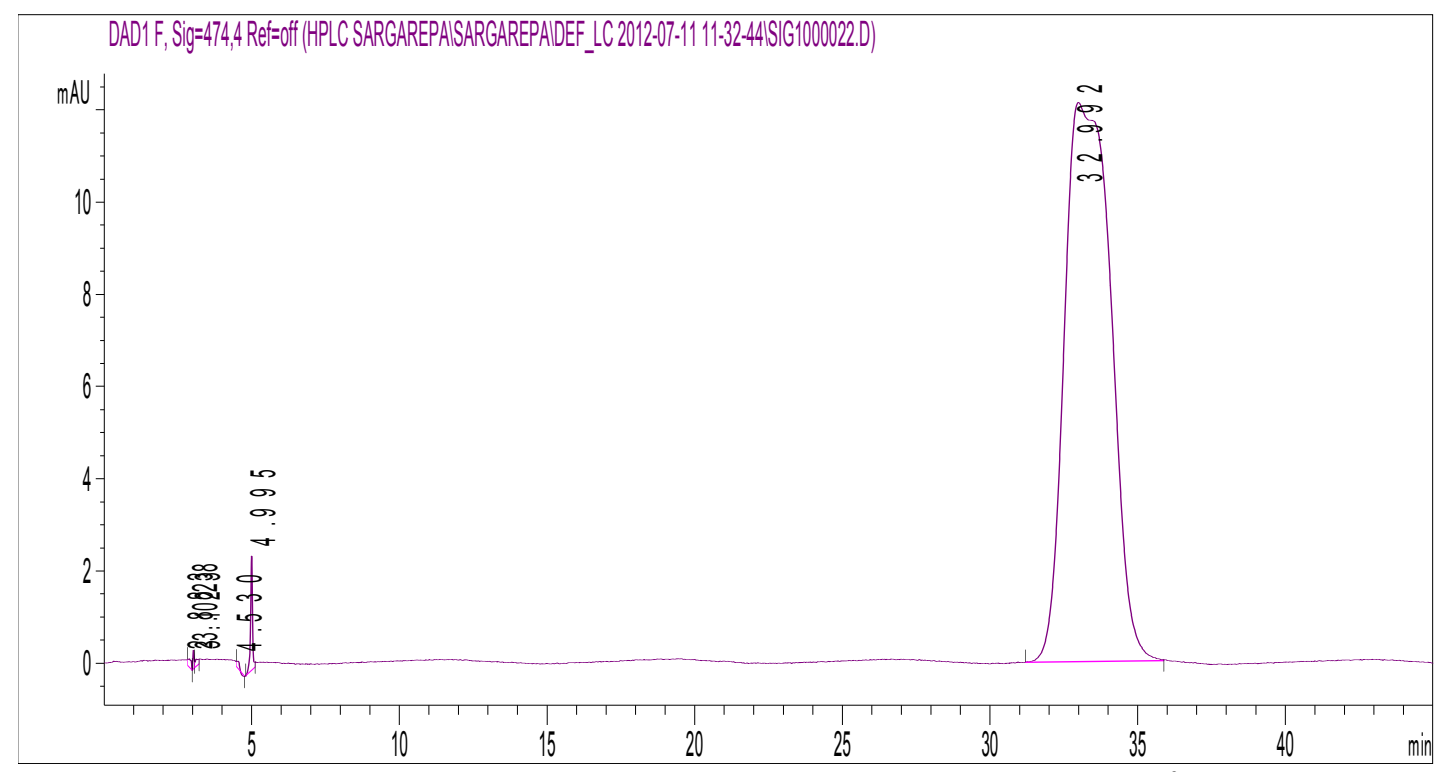

Figure 1. HPLC chromatogram of $\beta$-carotene $\left(\mathrm{c}=0,00625 \mathrm{mg} / \mathrm{cm}^{3}\right)$

\subsubsection{Calibration Curve for $\beta$-carotene Standard}

$\beta$-Carotene was dissolved in $n$-hexane just before HPLC analysis, and diluted to appropriate concentrations $\left(1.56-100 \mathrm{mg} / \mathrm{cm}^{3}\right)$ for calibration curve preparation of (Cvetkovic \& Markovic, 2008). The external standard method was used to determine the $\beta$-carotene concentration in the extracts. Calibration curve obtained from HPLC analysis of $\beta$-carotene in different concentrations is shown on (Figure 2).

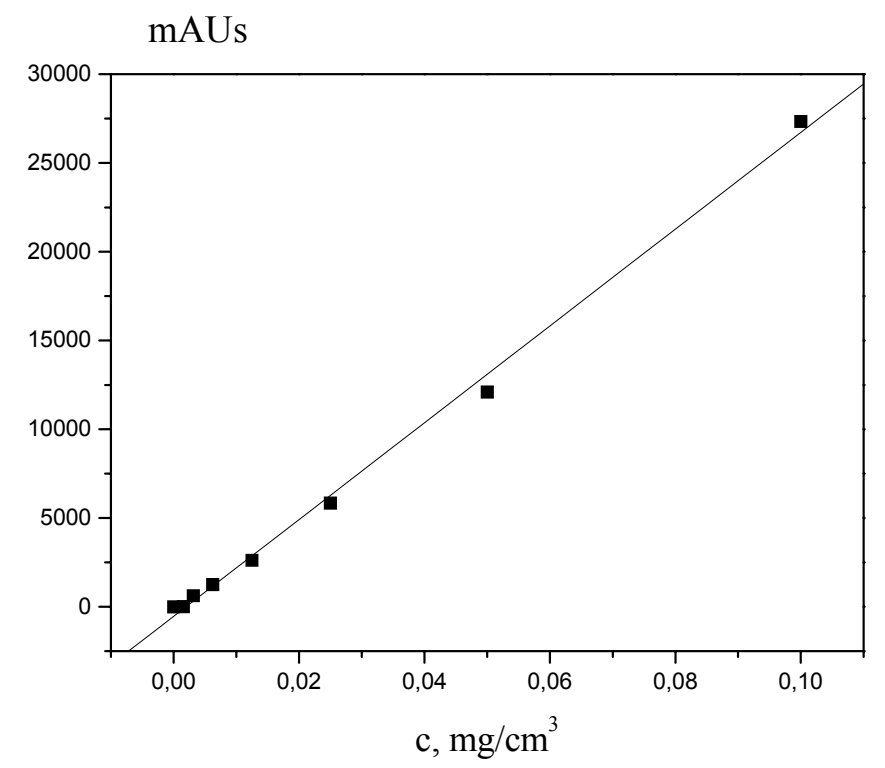

Figure 2. The calibration curve for determination of $\beta$-carotene content in carrot, based on HPLC analysis

\subsection{Vitamin $C$}

Vitamin C content was determined by Tillman's method'. The method is based on the extraction of L-ascorbic acid from the analysing sample by means of the oxalic acid and conversion of 2.6-dichlorphenolindophenol into dehydroascorbic acid. 


\subsection{Chemicals}

All chemicals and reagents were of analytical grade and were purchased from Sigma Chemical (St. Louis, MQ, USA), Aldrich Chemical Co. and Alfa Aesar (Karlsruhe, Germany).

\subsection{Data Analysis}

All data were subjected to one- or two-way statistical analysis at $\mathrm{P}=0.05$ using JMP6 Statistical Analysis Software Program (SAS Institute Inc. Cary, NC, USA).

\section{Results and Discussion}

Carrots have low metabolic activity at low temperatures, as shown by the low respiration rate. However, carrots are sensitive to wilting if not protected from water loss. The moisture content of the refrigerated carrots decreased with time of storage. The relative humidity measured inside the $\mathrm{S}_{1}$ sophisticated cooling room conditions ranged from $95 \%$ to $98 \%$, whereas the relative humidity under simple refrigerated storage varied from $79 \%$ to $94 \%$. The low relative humidity under the refrigerated storage may have contributed to the decrease in moisture content of the carrots with time.

Mass losses (shriveling) and fungal diseases were the most important causes of postharvest losses of carrot in Serbia. At the end of 180 days of storage the percentage mass losses ranged from $3.1 \%$ to $33.2 \%$ depending on the storage condition and disinfection treatment. Thus, the weight loss of carrot roots inside the $\mathrm{S}_{1}$ sophisticated cooling room conditions ranged from $3.1 \%$ with chlorinated $\left(175 \mathrm{ppm} \mathrm{Na}_{2} \mathrm{OCl}\right)$ prestorage treatment to a maximum weight loss of $6.8 \%$ in control (unwashed-control roots). A different trend was observed under simple refrigerated storage, where the lowest mass losses $(20.7 \%)$ were recorded in treatment with hydrogen-peroxide, but more significantly the highest mass losses $(33.2 \%)$ were observed with hot water treatment (Table 1$)$.

Table 1. Effect of postharvest treatments and storage conditions on mass losses (\%) during storage

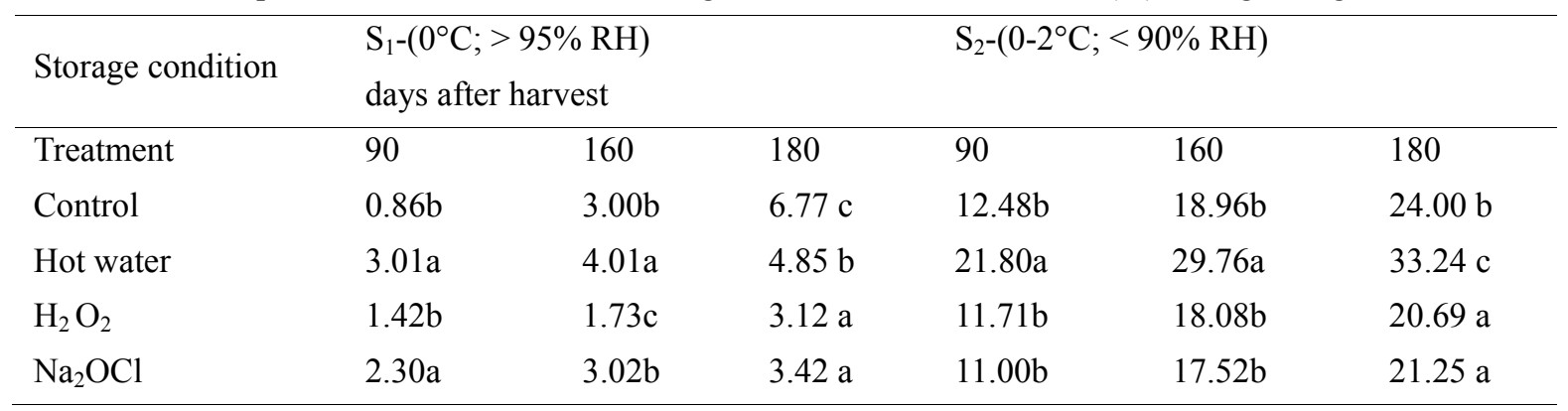

Similar results were found by Sudimac et al. (2012) who showed that the percentage mass losses ranged from $15 \%$ to $35 \%$ depending on the cultivars and disinfection treatment. Commercial storage of carrots resulted in mass losses of $15 \%$ fresh weight over a 3-month period (Ng et at., 1998). The effects of sanitation treatments were highly effective at reducing disease decay (A. alternata) in comparison with control (12\%). In view of microbial reduction and maintenance of sensory properties, the use of cold chlorinated water proved to be effective for washing carrots (Sudimac et al., 2012). The rate of water loss of a carrot is affected by the surface area of the root, the water vapour pressure deficit and air velocity (Correa et al., 2012). Water loss due to transpiration results in shrivelling, loss of bright colour and increased risk of postharvest decay. An 8\% weight loss is reported to make carrots unsaleable (Robinson et al., 1975).

$\beta$-caroten and vitamin $\mathrm{C}$ levels in the fresh carrot decrease during storage. Since carrots are an important source of carotenoids and vitamin $\mathrm{C}$ in the human diet, it is appropriate to determine to what extent these compounds are lost during storage. The carrot root is associated with the presence of certain carotenoids, xanthophylls or anthocyanins. In orange carrots, $\alpha$-carotene accounts for $15 \%$ to $40 \%$ of the total carotenoid content, while $\beta$-carotene accounts for $45 \%$ to $80 \%$ and $\gamma$-carotene for $2 \%$ to $10 \%$ of the total carotenoid content (Tang, 2010). At the end of 180 days of storage the percentage of $\beta$-carotene loss resulted in a significant reduction, particularly under simple refrigerated storage. Depending on the disinfection treatment the loss of $\beta$-carotene varied. Thus, loss of $\beta$-carotene in carrot roots inside the $S_{1}$ sophisticated cooling room conditions ranged from $4.1 \%$ with hot water prestorage washing treatment to a maximum of $20.7 \%$ in treatment with $\mathrm{Na}_{2} \mathrm{OCl}$ (Table 2). 
Table 2. Effect of postharvest treatments and storage conditions on $\beta$-carotene $(\mu \mathrm{g} / \mathrm{g}$ f.w) changes

\begin{tabular}{|c|c|c|c|c|c|c|c|}
\hline \multirow{3}{*}{$\begin{array}{l}\text { Storage condition } \\
\text { Treatment }\end{array}$} & & \multicolumn{3}{|c|}{$\mathrm{S}_{1}-\left(0^{\circ} \mathrm{C} ;>95 \% \mathrm{RH}\right)$} & \multicolumn{3}{|c|}{$\mathrm{S}_{2}-\left(0-2^{\circ} \mathrm{C} ;<90 \% \mathrm{RH}\right)$} \\
\hline & & \multicolumn{6}{|c|}{ days after harvest } \\
\hline & Time of harvest & 90 & 160 & 180 & 90 & 160 & 180 \\
\hline Control & 39.74 & $38.80 \mathrm{a}$ & $37.93 \mathrm{a}$ & $36.65 b$ & $37.90 \mathrm{a}$ & $34.05 a$ & $28.53 \mathrm{a}$ \\
\hline Hot water & & $39.21 \mathrm{a}$ & $38.92 \mathrm{a}$ & $38.12 \mathrm{a}$ & $37.15 \mathrm{a}$ & $32.10 \mathrm{~b}$ & $23.02 b$ \\
\hline $\mathrm{H}_{2} \mathrm{O}_{2}$ & & $37.54 b$ & $35.10 \mathrm{~b}$ & $33.52 \mathrm{c}$ & $35.02 b$ & $31.55 \mathrm{~b}$ & $24.79 \mathrm{~b}$ \\
\hline $\mathrm{Na}_{2} \mathrm{OCl}$ & & $36.86 \mathrm{~b}$ & $34.45 b$ & $31.51 \mathrm{c}$ & $34.10 \mathrm{~b}$ & $28.17 \mathrm{c}$ & $21.09 \mathrm{c}$ \\
\hline
\end{tabular}

A similar trend was observed under simple refrigerated storage, where the lowest $\beta$-carotene loss $(28.2 \%)$ was recorded in control roots and the highest $\beta$-carotene loss was observed in $\mathrm{Na}_{2} \mathrm{OCl}$ treatment (46.9\%).

Our findings that $\beta$-carotene is lost during storage and that this depends on the storage conditions is in agreement with findings by Fikselova et al. (2010), who similarly found that loss of $\beta$-carotene during carrot storage is higher in the cellar than in cold storage. The mean loss of $\beta$-carotene in dry matter for cold storage was $13.57-14.28 \%$, compared to $20-27.3 \%$ in the cellar (Fikselova et al., 2010). In Nantes carrots, stored at $2^{\circ} \mathrm{C}$ and 90 percent relative humidity, $\alpha$-carotene and $\beta$-carotene levels increased slowly through 100 to 125 days and then decreased (Lee, 1986). Losses in total carotenoid content were reported in some vegetables, especially leaves. Both sweet pepper and parsley lost over $20 \%$ of their total carotenoid content at cold room storage $\left(7^{\circ} \mathrm{C}\right)$ for 9 days (Takama \& Saito 1974). Carotenoid losses amounted to 60 and $80 \%$ at $15^{\circ} \mathrm{C}$ and $17^{\circ} \mathrm{C}$, respectively. Leek lost about $53 \%$ of its total carotenoid content within 3 days at both temperatures (Takama \& Saito, 1974).

The content of vitamin $\mathrm{C}$ in carrot can be influenced by various factors such as genotypic differences, preharvest climatic conditions and cultural practices, maturity and harvesting methods, and postharvest handling procedures. Temperature management after harvest is the most important factor to maintain vitamin $\mathrm{C}$ levels in vegetables; losses are accelerated at higher temperatures and with longer storage durations (Lee \& Kader, 2000).

The losses of vitamin $\mathrm{C}$ that occur immediately after harvest. 90-day storage resulted in a significantly larger reduction in vitamin $\mathrm{C}$ content under simple refrigerated storage (2-32.5\%) compared with the loss in a sophisticated cooling room (1-18.2\%), Tab 3. A more pronounced vitamin C loss was observed by Matejkova and Petrikova (2010) after 30 days of storage, a $47 \%$ reduction on average.

At the end of 180 days of storage the percentage of vitamin C loss resulted in a significant reduction particularly under simple refrigerated storage. Depending on the disinfection treatment the loss of vitamin $\mathrm{C}$ also varied. Thus, the vitamin $C$ losses of carrot root inside the $\mathrm{S}_{1}$ sophisticated cooling room conditions ranged from $2.0 \%$ with hot water prestorage washing to maximum vitamin $\mathrm{C}$ losses of $18.2 \%$ in treatment with $\mathrm{Na}_{2} \mathrm{OCl}$. A similar trend was observed under simple refrigerated storage, where the lowest vitamin C loss $(20.7 \%)$ was recorded in treatment with hot water treatment, but the highest vitamin $\mathrm{C}$ loss was observed with hydrogen-peroxide treatment (52.3\%), Table 3.

Table 3. Effect of postharvest treatments and storage conditions on vitamin $\mathrm{C}\left(\mathrm{mg} \cdot 100 \mathrm{~g}^{-1}\right)$ changes

\begin{tabular}{lccccccc}
\hline \multirow{2}{*}{ Storage condition } & \multicolumn{5}{c}{$\mathrm{S}_{1}-\left(0^{\circ} \mathrm{C} ;>95 \% \mathrm{RH}\right)$} & \multicolumn{5}{c}{$\mathrm{S}_{2}-\left(0-2^{\circ} \mathrm{C} ;<90 \% \mathrm{RH}\right)$} \\
& \multicolumn{6}{c}{ days after harvest } \\
\hline Treatment & Time of harvest & 90 & 160 & 180 & 90 & 160 & 180 \\
Control & $\mathbf{5 . 0 5}$ & $4.95 \mathrm{a}$ & $4.72 \mathrm{a}$ & $3.28 \mathrm{~b}$ & $4.80 \mathrm{a}$ & $4.07 \mathrm{a}$ & $2.97 \mathrm{~b}$ \\
$\mathrm{Hot}$ water & & $5.00 \mathrm{a}$ & $4.80 \mathrm{a}$ & $4.07 \mathrm{a}$ & $4.95 \mathrm{a}$ & $4.20 \mathrm{a}$ & $3.52 \mathrm{a}$ \\
$\mathrm{H}_{2} \mathrm{O}_{2}$ & $4.48 \mathrm{~b}$ & $4.35 \mathrm{~b}$ & $3.08 \mathrm{~b}$ & $4.10 \mathrm{~b}$ & $3.41 \mathrm{~b}$ & $2.56 \mathrm{c}$ \\
$\mathrm{Na}_{2} \mathrm{OCl}$ & $4.40 \mathrm{~b}$ & $4.18 \mathrm{~b}$ & $2.86 \mathrm{~b}$ & $4.30 \mathrm{~b}$ & $3.99 \mathrm{a}$ & $2.41 \mathrm{c}$ \\
\hline
\end{tabular}

Favell (1998) noted a $15 \%$ decrease of vitamin $\mathrm{C}$ in carrot after 14 days storage at $4{ }^{\circ} \mathrm{C}$. Fresh storage at ambient temperatures resulted in greater loss. For example, fresh peas stored at ambient temperatures lost $50 \%$ of their 
ascorbic acid in 1 week, while fresh spinach stored at ambient temperatures lost $100 \%$ of its ascorbic acid in less than 4 days (Hunter \& Fletcher, 2002).

\section{Conclusions}

This work confirms the existence of important differences between storage condition and postharvest washing treatments during carrot storage, regarding mass, vitamin $C$ and $\beta$-carotene losses. Losses of mass, $\beta$-carotene and vitamin $\mathrm{C}$ during carrot storage were greater in the simple cooling room compared to the sophisticated cold storage. After 180 days of storage the levels of both $\beta$-carotene and vitamin $\mathrm{C}$ were significantly lower with the largest losses noted for vitamin C.

This research revealed that prestorage root washing (175 ppm sodium hypochlorite) significantly reduced weight loss, while hot water treatment maintained a good quality of $\beta$-carotene and vitamin $\mathrm{C}$ contents in the carrot.

\section{Acknowledgements}

This study is part of the TR-31027 project entitled 'Organic agriculture-Improvement of production using fertilizers, bio-products and biological methods' and TR-34012 project entitled "Plant and synthetic bioactive products of new generation", financially supported by the Ministry of Science and Technological Development, Republic of Serbia.

\section{References}

Afek, U., Orenstein, J., \& Nuriel, E. (1999). Steam treatment to prevent carrot decay during storage. Crop Protection, 18, 639-642. http://dx.doi.org/10.1016/S0261-2194(99)00065-4

Alasalvar, C., Grigor, J. M., Zhang, D., Quantick, P. C., \& Shahidi, F. (2001). Comparison of volatiles, phenolics, sugars, antioxidant vitamins and sensory quality of different colored carrot varieties. Journal of Agricultural Food Chemistry, 49(3), 410-1416. http://dx.doi.org/10.1021/jf000595h

Correa, P. C., Farinha, L. R. L., Finger, F. L., Oliveira, G. H. H., Campos, S. C., \& Bohelto, F. M. (2012). Effect of physical characteristics on the transpiration rate of carrots during storage. Acta Horticulturae, 934, 1341-1346.

Cvetkovic, D., \& Markovic, D. (2008). UV-induced changes in antioxidant capacities of selected carotenoids toward lecithin in aqueous solution. Radiation Physics and Chemistry, 77, 34-41. http://dx.doi.org/10.1016/j.radphyschem.2007.02.078

Eshel. D., Regev, R., Orenstein, J., Droby, S., \& Gan-Mor, S. (2009). Combining physical, chemical and biological methods for synergistic control of postharvest diseases: A case study of black root rot of carrot. Postharvest Biolology and Technology, 54(1), 48-52. http://dx.doi.org/10.1016/j.postharvbio.2009.04.011

Favell, D. J. (1998). A comparison of the vitamin C content of fresh and frozen vegetables. Food Chemistry, 62, 59-64. http://dx.doi.org/10.1016/S0308-8146(97)00165-9

Fikselova, M., Marecek, J., \& Mellen, M. (2010). Carotenes content in carrot roots (Daucus carota L.) as affected by cultivation and storage. Vegetable Crops Research Bulletin, 73, 47-54. http://dx.doi.org/10.2478/v10032-010-0017-8

Hunter, K. J., \& Fletcher, J. M. (2002). The antioxidant activity and composition of fresh, frozen, jarred and canned vegetables. Innov. Food Science Emerging Technology, 3, 399-406. http://dx.doi.org/10.1016/S1466-8564(02)00048-6

Ilić, S. Z., Fallik, E., \& Dardić, M. (2009). Harvest, sorting, packing and storage vegetables. Publisher: University of Priština, Faculty of Agriculture-Kosovska Mitrovica (pp. 69-90).

Klaiber, R. G., Baur, S., Wolf, G., Hammes, W. P., \& Carle, R. (2005). Quality of minimally processed carrots as affected by warm water washing and chlorination. Innovative Food Science Emerging Technologies, 6(3), 351-362. http://dx.doi.org/10.1016/j.ifset.2005.03.002

Lee, C. Y. (1986). Changes in carotenoid content of carrots during growth and post-harvest storage. Food Chemistry, 20, 285-293. http://dx.doi.org/10.1016/0308-8146(86)90097-X

Lee, S. K., \& Kader A. A. (2000). Preharvest and postharvest factors influencing vitamin C content of horticultural crops. Postharvest Biology and Technology, 20, 207-220. http://dx.doi.org/10.1016/S0925-5214(00)00133-2

Matějková, J., \& Petř́ková, K. (2010). Variation in content of carotenoids and vitamin C in carrots. Notulae Scientia (Biologicae), 2(4), 88-91. 
Ng, A., Srruth, A. C., \& Waldron, K. (1999). Cell wall chemistry of carrots (Daucus carota cv Amstrong) during maturation and storage. Proceedings of the $7^{\text {th }}$ Internaiumal Working Conference on Stored-product Protection (Volume 2, pp. 1693-1697).

Robinson, J. E., Browne, K. M., \& Burton, W. G. (1975). Storage characteristics of some vegetables and soft fruits. Annals of Applied Biology, 81, 399-408. http://dx.doi.org/10.1111/j.1744-7348.1975.tb01656.x

Stoll, K., \& Weichmann, J. (1987). Root vegetables. In J. Weichmann (Ed.), Postharvest physiology of vegetables (pp. 541-553). Dekker, New York.

Sudimac, M., Ilić, S. Z., Škrbić, N., \& Marinković, D. (2012). Improvements in washing and sanitizing technology on quality characteristics of carrots during prolonged storage. Contemporary Agriculture, 61(Special), 99-105.

Takama, F., \& Saito, S. (1974). Studies on the storage of vegetables and fruits. II. Total carotene content of sweet pepper, carrot, leek and parsley during storage. Journal of Agricultural Science (Japan.), 19, 11.

Tang, G. (2010). Bioconversion of dietary provitamin A carotenoids to vitamin A in humans. American Journal of Clinical Nutrition, 91(suppl), 1468S-1473S. http://dx.doi.org/10.3945/ajcn.2010.28674G 